\title{
CHROMOLAENA ODORATA IN DIFFERENT ECOSYSTEMS: WEED OR FALLOW PLANT?
}

\author{
KOUTIKA, L.-S. ${ }^{1} *$ - RAINEY, H.J. ${ }^{2}$ \\ ${ }^{1}$ B.P.4895, Pointe-Noire, Republic of Congo \\ (phone: +242-695-84-40/+242-559-37-47/+242-440-92-64) \\ ${ }^{2}$ Northern Plains Project and Cambodia vulture Conservation Project, Wildlife Conservation \\ Society - Cambodia Program, PO Box 1620, Phnom Penh, Cambodia. \\ *Corresponding author \\ e-mail:ls_koutika@yahoo.com \\ (Received $4^{\text {th }}$ January 2008 ; accepted $25^{\text {th }}$ January 2010)
}

\begin{abstract}
To understand the use of Chromolaena odorata in different agricultural systems and ecosystems, findings of several scientific studies conducted in different areas have been assessed in this review paper. Some authors considered $C$. odorata as a serious weed because of its ability: to regenerate and colonize uninvaded areas; to be a threat to some ecosystems and environment; to reduce the biodiversity of grasslands, savannahs and forests; and to be a considerable problem in commercial tree plantations as it suppresses the growth of young pine and eucalypt trees. Others argued that the species may be considered as a beneficial fallow plant rather than a weed, because it may be considered as a welcome plant rather than a weed in some agricultural systems, when considering the expected properties of species for fallow improvement. The following are the main reasons why $C$. odorata is considered as a fallow because of it ability: to be a nutrient sink and its potential benefit to the crop as regular source of organic matter and nutrients after slashing; to have a beneficial effect on exchangeable $\mathrm{K}$ concentration; to be used as green manure; to be better adapted as a fallow plant on acidic soils than some leguminous.
\end{abstract}

Keywords: tropical and subtropical ecosystems, invasive plant.

\section{Introduction}

Chromolaena odorata (L), King \& Robinson (Asteraceae, Eupatorieae) is a perennial shrub forming dense tangled bushes 1.5-2.0 $\mathrm{m}$ in height, occasionally reaching $6 \mathrm{~m}$ as a scrambler up trees. $C$. odorata originated in subtropical and tropical America, and had a wide native distribution, from the southern United States to northern Argentina, and exhibits considerable variation throughout its distribution (Holm et al., 1977). MacFadyen Cruttwell (1996) argued that the source of the original introduction is likely to have been Jamaïca in the West Indies. In the Neotropics C. odorata is always found in competition or association with a complex of closely related species not present in Asia or Africa (MacFadyen Cruttwell, 1991). In the new world, C. odorata is common in most habitats except undisturbed rainforest. It is typically a plant of secondary succession, rapidly invading clearings and persisting until shaded out by the overgrowth of forest trees (MacFadyen Cruttwell, 1991). Almeida-Neto and Lewinsohn (2004) investigated the spatial distribution of $C$. odorata, in its native habitat in the Reserva Biologica e Estaçao Experimental de Mogi-Guaçu, Sao Paulo State, Brazil. The authors concluded that the spatial autocorrelation in phenologial traits between $C$. odorata neighbours may be driven by genetic similarity among neighbouring plants and/or spatial structuring of environmental factors.

Nowadays, this shrub is widespread in subtropical and tropical areas all over the world due to its fast invasion or colonisation and its facility to regenerate; $C$. odorata regenerates and colonises equally as well through its roots or by high seed production

APPLIED ECOLOGY AND ENVIRONMENTAL RESEARCH 8(2): 131-142. http://www.ecology.uni-corvinus.hu • ISSN 15891623 (Print) • ISSN 17850037 (Online) (c) 2010, ALÖKI Kft., Budapest, Hungary 
and it is also well dispersed by wind. $C$. odorata is present in different agricultural systems of its native continent (MacFadyen Cruttwell and Skarratt, 1996), but also of colonized continents such as Asia (Nemoto et al., 1983 ; Roder et al., 1995), Africa, mainly in slash-and-burn systems (Olaoye, 1986; Rouw de, 1991; Obatulu and Agboola, 1993) and Oceania (Michael, 1989; MacFadyen Cruttwell, 1989). C. odorata was introduced into Asia in the 1840s, probably through the Serampore Botanical Gardens at Calcutta (MacFadyen Cruttwell, 1989; MacFadyen Cruttwell and Skarratt, 1996). From Calcutta, C. odorata spread east into Burma, and then progressively through Indonesia and Indochina (MacFadyen Cruttwell, 1989). C. odorata presence was reported in the late 1920s in Laos (Vidal, 1960) and in 1922 in Thailand (Kerr, 1932), and is wide spread in other Asian countries (Nakano, 1978, Roder et al., 1995). C. odorata was introduced into West Africa in 1936-1937 as seeds mixed with seeds of Gmelina arborea in Enugu (Nigeria) from Sri Lanka (Odukwe, 1965). Using the enzymatic diversity in $C$. odorata, Lanaud et al. (1991) supported the theory that $C$. odorata was introduced to Africa from Asia. From West Africa, C. odorata has since spread to the Central Africa, i.e., Cameroon, Central African Republic, Democratic Republic of Congo and Republic of Congo in the northern and southern part of the country (Prasad et al., 1996). MacFadyen Cruttwell and Skarratt (1996) have established a dynamic simulation model to estimate of $C$. odorata's geographical distribution and relative abundance as determined by climate, and found that the potential distribution coincided with the area invaded and it has reached its apparent climatic limits in West Africa. $C$. odorata was introduced in 1940 in South Africa, and has naturalized and invaded most of tropical and sub-tropical regions of the country (Delfino Abeya, 2002). C. odorata spread rapidly towards Australia and the Pacific region. In 1985, Australian weed scientists started a campaign as the species was identified as the greatest weed threat to the northern part of country, because of its rapid spread and its high potential to damage agriculture and the environment (Michael, 1989). Using climatic comparisons, MacFadyen Cruttwell (1989) found that much of the tropical and subtropical coastal land from the Kimberley's in Western Australia to Brisbane, was suitable for invasion by this species.

As shown in Table 1, the use of C. odorata is somewhere controversial (Roder et al., 1995; Weise and Tchamou, 1999). Some researchers considered C. odorata as a weed (Olaoye, 1986; Rouw de, 1995; Waterhouse, 1994; MacFadyen Cruttwell, 1996) or a beneficial fallow plant (Ekeleme et al., 2004; Norgrove et al., 2000; Koutika et al., 2005a). Therefore, the aim of this review paper is to present selected research and findings which considered $C$. odorata as a weed or as a beneficial fallow plant and to show how would its use affect any decision on classical biological control and environment management. On balance, $C$. odorata is more a weed or a beneficial plant?

\section{C. odorata as a weed}

In this part of the review we make a summary of the factors that would allow a farmer to decide to eliminate the species, according to crop, soil or climate. Chromolaena odorata is an aggressive pioneer shrub species, which is regarded as a very serious threat to agriculture and the environment in most invaded countries. The high productivity of light seeds allows the species to invade disturbed sites in a short period of time (Holm et al., 1977; Swaine et al., 1997). The rapid spread of the weed is due to extensive seed production which is estimated to be 93,000-160,000 seeds/plant

APPLIED ECOLOGY AND ENVIRONMENTAL RESEARCH 8(2): 131-142. http://www.ecology.uni-corvinus.hu • ISSN 15891623 (Print) • ISSN 17850037 (Online) (C) 2010, ALÖKI Kft., Budapest, Hungary 
(Wilson, 1995), and also through wind dispersal of seeds (MacDonald and Frame, 1988). There are other specific characteristics such as quick germination of plants, which grow to $2 \mathrm{~m}$ and form a dense woven canopy that is almost impossible for tree seedling to grow through (Riddock et al., 1991); the understory only receives about $70 \%$ of full sunlight (Honu and Dang, 2000). All these characteristics have caused many researchers to recognize $C$. odorata as a serious weed in countries where it grows (Olaoye, 1986; Michael, 1989; Roder et al., 1994; MacFadyen Cruttwell and Skarratt, 1996).

In addition, $C$. odorata is considered as an alien invasive species which negatively impacts the forest in economic, ecological and environmental and social and health terms (Holm et al., 1977; Moore, 2004). It is also considered as a considerable threat to conservation and ecotourism, as it has first invaded natural area, reducing the biodiversity of grasslands, savannahs and forests (MacDonald, 1983; Goodall and Erasmus, 1996; Matthews and Brand, 2004). C. odorata has been found to threaten the breeding habitat of the Nile crocodile Crocodylus niloticus in South Africa, by decreasing the temperature of nesting sites by shading and crowding and this can induce female biased sex ratios or may even prevent embryotic development altogether (Leslie and Spolita, 2001). C. odorata is a considerable problem in commercial tree plantations as it suppresses the growth of young pine and eucalypt trees and allows fire and to penetrate deeper into plantations (Matthews, 2004; Matthews and Brand, 2004). It can also promote wildland fires (Moore, 2004). C. odorata may also cause skin problems and asthma in allergy-prone people.

Kriticos et al. (2005) revised a climate model of the estimated potential distribution of $C$. odorata. The authors argued that the revised model reduces the estimated potential distribution of $C$. odorata, particularly in terms of the poleward and inland extents of suitable climates. This model shows that Mediterranean, semi-arid and temperate climates are predicted to be unsuitable, and supports the previous conclusions that much of tropical Africa, the north-eastern coast of Australia and most Pacific islands are at risks of invasion. Joshi et al. (2006) investigated the possibility of indirect mapping techniques to localize areas, where $C$. odorata was capable of expressing its invasive traits. The authors found that $C$. odorata was frequently observed in forest too shaded for seed production and argued that the presence of $C$. odorata under conditions unfavourable for seed production implies continuous re-colonization of such sites from adjacent seed production populations.

In South Africa, Kluge and Zachariades (2006) found Lixus aemulus, a stem-boring weevil imported from Brazil caused 66.6\% mortality of the stems and reduced the dry mass of infested $C$. odorata stems by $46.6 \%$ in a damage trial in pots. Van Gils et al. (2005) argued that promoting a closed tree canopy cover itself will not be sufficient to control C. odorata at Mtubatuba municipability of $20 \mathrm{~km}$ (west to east) and $10 \mathrm{~km}$ (north to south) in South Africa. While studied allelopathic effects of C. odorata (R.M. King and Robinson) toxin on tomatoes (Lycopersicum esculentum Mill), OnwugbutaEnyi (2001) found significant growth reduction of the latter species with $C$. odorata aqueous-leaf extract at concentrations as low as $1 \mathrm{~g}$ fresh weight in $40 \mathrm{ml}$ of water. The author concluded that the presence of $C$. odorata in a field may result in the accumulation of leachates and residues that are toxic to crops resulting in yield losses.

Similarly, Ambica and Jayachandra (1980) argued that $C$. odorata possesses allelopathic potentialities and growth inhibitors. Prashanti and Kulkarni (2005) proposed that $C$. odorata is a threat to agriculture and environment. They reported that 
there is an urgent need to manage weed growth and its spread so as to maintain ecological integrity of habitats. It was found that $C$. odorata could be controlled by the introduction of natural enemies. The genetically homogeneous population structure in weeds makes it easier to match a biological control agent to host genotypes and makes this species particularly vulnerable to biological enemies (Van Driesche and Bellows, 1996; Muniappan and Marutani, 1991) argued that mechanical control is labor intensive and not long lasting; cultural control is long lasting, however either mechanical or chemical control program has to be carried out initially to implement the cultural control; while chemical is effective, but expensive, and poses some environmental problems. Ye et al. (2004) studied a genetic structure of the invasive C. odorata in China. The authors argued that because the genetic variation of $C$. odorata is very low, if a suitable biological enemy was identified effective for control, the various populations of $C$. odorata in China could have a uniform response to this biological control.

In the upland rice fields of some areas of Laos, $C$. odorata is the most important weed. However, the interviewed elderly persons could not recollect the dominant weed species before the $C$. odorata invasion (Roder et al., 1994). In Ghana, poor natural forest regeneration is due to the invasion of deforested areas by $C$. odorata (Honu and Dang, 2000). However, Honu and Dang (2000) argued that tree seedlings were observed under $C$. odorata canopy and these seedlings positively responded to the removal of the shrub. These findings indicated that release treatment may be an effective way to restore forest to sites previously occupied by $C$. odorata. Chandrasekaram and Swamy (2002) estimated the biomass, litter production and aboveground net production of herbaceous community and analysed vegetation composition in natural and man-modified ecosystems. The authors found that exotic plant invasions such as those by $C$. odorata influence ecosystem structure, species composition and ANPP, and argued that the sustainable use of these weeds (extracted from plantations) as an organic mulch in the establishment of young banana plantation, needs to be encouraged to manage its effectiveness. In Southern China, establishment of signal grass (Brachiaria decumbens Stapf) in pasture has effectively prevented germination of the seeds and growth of the seedlings of $C$. odorata (Renrun and Xuejun, 1991). They found that a few seedlings of C. odorata may grow in the first two years after establishment of Brachiaria decumbens. However in the third year virtually no $\mathrm{C}$. odorata is noted in these fields.

Some farmers did not consider $C$. odorata as an aggressive shrub species. Thus, some farmers of Laos found it relatively easy to remove $C$. odorata from the young plants when it regrew from rootstock after burning. They said that $C$. odorata growing from seeds had a comparatively low initial growth phase and was not a big problem in the initial growth stage of the rice plant (Roder et al., 1995). Furthermore, even though C. odorata accounted for $48 \%$ of total biomass after the first year of fallow against $37 \%$ fallow tree and bamboo species, plant density and percent contribution declined in the second year of fallow in northern Laos (Roder et al., 1995). Similarly, C. odorata contributed $80 \%$ of the canopy cover and was the dominant fallow species (Roder et al., 1995). All the findings cited have shown that $C$. odorata is a weed and that classical biological control is used to its iradication. 


\section{C. odorata as a beneficial fallow plant}

In this second section, we made a summary of the factors that would allow a farmer to decide to grow the species, according to crop, soil or climate. The fallow period is used to limit the development of weeds because they threaten the re-use of the land (Rouw de, 1995). When considering the expected properties of species for fallow improvement such as ease of establishment, large biomass, fast decomposition rate, weed suppression, $C$. odorata may be considered as a welcome plant rather than a weed in some slash-and-burn systems (Dove, 1986; Ikuenobe and Analiefo, 2003; Koutika et al., 2005a; Norgrove, 2007). Ikuenobe and Analiefo (2003) argued that infestation of weeds was lower in plots cropped after $C$. odorata than in the modified natural bush fallow in Nigeria. C. odorata grows dense canopy cover in a short space of time and was able to suppress other plant growth. Moreover, no correlation has been found between period and selected soil fertility parameters and frequency of $C$. odorata (Roder et al., 1995). Nevertheless $85 \%$ of farmers appreciated $C$. odorata and qualified it as a 'good fallow plants' or plant they like to have in their fallow fields in northern Laos (Roder et al., 1995).

These authors argued that various explanations might be given for the preference of C. odorata: absence of negative effects on rice yield; relative ease of control by hand weeding in the rice crop; and fast growth and large biomass production. Some farmers suggested that soil structure improved where $C$. odorata is dominant compared to the fields with dominant bamboo species (Roder et al., 1994). Ngobo et al. (2004) argued that frequently farmed $C$. odorata-dominated short fallows were also characterized by higher litter and crown cover but lower tree basal area and canopy height, compared with bush fallow that had been a forest in the precedent cropping cycle. In addition, Ngobo et al. (2004) found that weed infestations were less rampant on plots planted following a $C$. odorata dominated fallow than on fields established following a short fallow not dominated by $C$. odorata. Being a dominant weed and fallow species in slash-and-burn agriculture of humid forest zone in Cameroon, Ngobo et al. (2004) argued that, as for the findings of Roder et al. (1995) and Ikuenobe and Analiefo (2003), some of the properties that render $C$. odorata as a 'good' fallow plant: namely fast development during the cropping phase, thus provide protective cover and allow better weed suppression than fallow systems not dominated by $C$. odorata.

Koutika et al. (2002) argued that $C$. odorata performed better than Pueraria leguminous fallow in acidic soils of southern Cameroon. Furthermore, Koutika et al. (2005a) found that $C$. odorata is more adapted to acidic soils than both Pueraria and Calliandra calothyrsus in central southern Cameroon, $C$. calothyrsus more adapted to nonacidic soils. However, in some situations of nonacidic soils, leguminous Pueraria may perform better or similar to $C$. odorata. Koutika et al. (2005b) argued that $C$. odorata is a good fallow option in the humid forest zone according to soil acidity and nutrient concentrations, while Kanmegne et al. (1999) also argued that $C$. odorata lead to an improvement of soil properties. In central-southern Cameroon, Kanmegne et al. (1999) showed that $C$. odorata had a beneficial effect on exchangeable K concentration on a sandy soil developed on granites and on a sandy clayey soil developed on gneiss, by comparing natural fallow dominanted by $C$. odorata and fallow where $C$. odorata had been removed by hand. 
Table 1. Chromolaena odorata as a weed or a fallow plant according to different researches

\begin{tabular}{|c|c|c|c|}
\hline References & Localities & As a weed & As a fallow \\
\hline [1] Almeida-Neto \& Lewinsohn (2004) & Brazil & $*$ & \\
\hline [2] Ambica \& Jayachandra (1980) & - & $*$ & \\
\hline [3] Chandrasekaram \& Swamy (2002) & South India & $*$ & \\
\hline [4] Delfino Abeya (2002) & South Africa & * & \\
\hline [5] Dove (1986) & Indonesia & * & \\
\hline [6] Ekeleme et al. (2004) & Nigeria & * & \\
\hline [7] Fuambeng Yonghachea et al. (2005) & Cameroon & * & \\
\hline [8] Goodall \& Erasmus (1996) & South Africa & * & \\
\hline [9] Holm et al. (1977) & Tropic\&Subtropic & * & \\
\hline [10] Honu \& Dang (2000) & Ghana & $*$ & \\
\hline [11] Ikuenobe \& Analiefo (2003) & Nigeria & & * \\
\hline [12] Joshi et al. (2006) & Central Nepal & * & \\
\hline [13] Kerr (1932) & India, Birmania & $*$ & \\
\hline [14] Kanmegne et al. (1999) & Cameroon & & $*$ \\
\hline [15] Kluge \& Zachariades (2006) & South Africa & * & \\
\hline [16] Koutika et al. (2001) & Cameroon & & * \\
\hline [17] Koutika et al. (2002) & Cameroon & & $*$ \\
\hline [18] Koutika et al. (2004) & Cameroon & & * \\
\hline [19] Koutika et al. (2005a) & Cameroon & & $*$ \\
\hline [20] Koutika et al. (2005b) & Cameroon & & $*$ \\
\hline [21] Koutika \& Meuteum-Kamga (2006) & Cameroon & & * \\
\hline [22] Kriticos et al. (2005) & Tropic\&Subtropic & * & \\
\hline [23] Lanaud et al. (1991) & Africa & $*$ & \\
\hline [24] Litzenburgen \& Ho Tong Lip (1961) & Cambodia & & $*$ \\
\hline [25] Leslie and Spotila (2001) & South Africa & $*$ & \\
\hline [26] MacDonald (1983) & South Africa & $*$ & \\
\hline [27] MacDonald \& Frame (1988) & South Africa & $*$ & \\
\hline [28] Matthews (2004) & Asian countries & $*$ & \\
\hline [29] Matthews \& Brand (2004) & African countries & $*$ & \\
\hline [30] McFadyen Cruttwell (1989) & Australia & $*$ & \\
\hline [31] McFadyen Cruttwell (1991) & Australia & $*$ & \\
\hline [32] McFadyen Cruttwell (1996) & Australia & * & \\
\hline [33] McFadyen Cruttwell \& Skarratt (1996) & Tropic\&Subtropic & $*$ & \\
\hline [34] Michael (1989) & Australia & * & \\
\hline [35] Moore (2005) & Tropic\&Subtropic & * & \\
\hline [36] Muniappan \& Marutani (1991) & Tropic\&Subtropic & $*$ & \\
\hline [37] Nakano (1978) & Thailand & $*$ & \\
\hline [38] Nemoto et al. (1983) & Northeast Thailand & $*$ & \\
\hline [39] Ngobo et al. (2004) & Cameroon & & * \\
\hline [40] Norgrove et al. (2000) & Cameroon & & $*$ \\
\hline [41] Norgrove et al. (2007) & Cameroon & & $*$ \\
\hline [42] Obatolu \& Agboola (1993) & Nigeria & & $*$ \\
\hline [43] Odukwe (1965) & Nigeria & $*$ & \\
\hline [44] Olaoye Soa (1986) & Nigeria & $*$ & \\
\hline [45] Onwugbuta- Enyi (2001) & Nigeria & $*$ & \\
\hline [46] Prashanthi \& Kulkarni (2005) & India & $*$ & \\
\hline [47] Prasad et al. (1996) & India & $*$ & \\
\hline [48] Renrun \& Xuejun (1991) & China & $*$ & \\
\hline [49] Riddock et al. (1991) & Nigeria & $*$ & \\
\hline [50] Roder et al. (1994) & Laos & $*$ & \\
\hline [51] Roder et al. (1995 & Northern Laos & $*$ & \\
\hline [52] Rouw de (1991) & Ivory Coast & & $*$ \\
\hline [53] Rouw de (1995) & Tropic\&Subtropic & & $*$ \\
\hline [54] Swaine et al. (1997) & Ghana & * & \\
\hline [55] Tian et al. (1998) & Nigeria & & $*$ \\
\hline [56] Tian et al. (2005) & Nigeria & & $*$ \\
\hline [57] Vidal (1960) & Laos & $*$ & \\
\hline [58] Van Driesche \& Bellows (1996) & Tropic\&Subtropic & & * \\
\hline [59] Van Gils et al. (2005) & South Africa & $*$ & \\
\hline [60] Waterhouse (1994) & Southeast Asia & $*$ & \\
\hline [61] Weise \& Tchamou (1999) & Cameroon & $*$ & $*$ \\
\hline [62] Wilson (1995) & South Africa & $*$ & \\
\hline [63] Ye et al. (2004) & China & $*$ & \\
\hline
\end{tabular}


Furthermore, $\mathrm{NH} 4^{+}-\mathrm{N}$ mineralization was smaller in leguminous fallow than in $C$. odorata fallow and depended on intrinsic soil properties (Koutika et al., 2004). $C$. odorata has a fast decomposition rate and might improve SOM quantity and quality (Norgrove, 2007). In fact, C. odorata decomposed fast with only $36 \%$ of its original weight remaining after 14 weeks (Kanmegne et al., 1999). Litzenburgen and Tong (1961) argued that $C$. odorata might be used as green manure with good results for low land rice. On an isohyperthermic Typic Kandiudult (USDA), Koutika et al. (2001) found that biological and chemical fertility under leguminous fallow (Pueraria phaseoloides and Mucuna pruriens) were higher than under natural regrowth (mainly composed of $C$. odorata, Paspalum conjugatum and Ageratum conizoides). The authors found that the beneficial effect of the legumes on $\mathrm{N}$ content in particulate organic matter (POM), one of active form of SOM, was small, but yet statistically significant after only 9 months of fallow.

POM and cumulative mineralized $\mathrm{C}$ values under $C$. odorata were better under fallow where $C$. odorata had been removed, underlining the possible management of this fallow type even though because of reduced weed control, removing C. odorata may bring more problems to farmers (Kanmegne et al., 1999). In fact $C$. odorata management may promote the sustainability of a cropping system in the area, since in some cases soil characteristics under natural fallow with dominantly $C$. odorata had closer beneficial relationships with crop yields (maize, groundnut and cassava) than leguminous Pueraria (Kanmegne et al., 1999). Moreover, Tian et al. (1998) found higher performance of maize after cover crop-fallow relative to the natural fallow with dominantly $C$. odorata, and argued that Pueraria could be a better alternative to the natural fallow with dominant $C$. odorata in sustaining soil productivity over a shortened period of fallow. In addition, Tian et al. (2005) showed that Pueraria cover fallow with 1 year fallow length could be a better alternative to natural $C$. odorata regrowth fallow for higher maize yield, and Leucaena alley cropping with 1 year fallow length could be a better alternative to natural regrowth fallow for maintenance of soil organic matter.

Nevertheless, one study conducted in low acidic soil of central Cameroon, found that it was not necessary to replace $C$. odorata with planted leguminous fallow since it performed better or equal to planted fallow, and $C$. odorata could be considered a beneficial fallow plant rather than be considered a weed (Koutika et al., 2005b). Studies conducted in central-southern Cameroon have shown that $C$. odorata is better adapted as a fallow plant on acidic soils (Kanmegne et al., 1999, Koutika et al., 2005a) and higher level of POM, an active part of SOM, might be observed in the acidic Typic Kandiudox compared to the Typic Kandiudult (Koutika et al., 2006). However, the quality of POM ( $\mathrm{C}$ and $\mathrm{N}$ contents in fractions) remains lower indicating that sustainable crop production might be good after chemical constraints are alleviated. A survey conducted in the North West, South West and Littoral provinces of Cameroon, has shown that all farmers perceived $C$. odorata-dominated fallow to indicate softer and more fertile soils than Imperata cylindrica; the soils in which the latter species is found, require very high labour input for land preparation (Fuambeng Yonghachea et al., 2005). C. odorata was most effective in weed suppression and in fields where it was the fallow plant there was the lowest weed biomass compared to bamboo or other fallow species (Roder et al., 1995). While evaluating the size and composition of weed communities under different planted fallow in a rotational hedgerow intercropping system in the forest/savannah transition zone in Nigeria, Ekeleme et al. (2004) considered $C$. odorata as a fallow plant rather than a weed. The authors considered $C$.

APPLIED ECOLOGY AND ENVIRONMENTAL RESEARCH 8(2): 131-142. http://www.ecology.uni-corvinus.hu • ISSN 15891623 (Print) • ISSN 17850037 (Online) (c) 2010, ALÖKI Kft., Budapest, Hungary 
odorata as a natural fallow plant, which was better at reducing weed growth than the planted fallow Leucaena leucocephala. Therefore several findings have shown that most farmer of appropriate region (part of Africa and Asia) may decide to grow the species as fallow according to its response to crop productivity and soil characteristics improvement.

\section{Conclusions}

It is apparent that the use of $C$. odorata is controversial as found by some authors (Roder et al., 1995; Weise and Tchamou, 1999). C. odorata may be considered either as a weed, i.e., an invasive plant species or as a beneficial fallow plant necessary to sustain agriculture in some part of the world (Table 1.). Thus, in some invaded countries as Nigeria, Australia, South Africa and Laos, C. odorata is considered as an aggressive invasive species and a very serious threat to agriculture and the environment (Olaoye, 1986; MacFadyen Cruttwell, 1989; Michael, 1989; Roder et al., 1994).

In fact, because of its negative impact on the forest in terms of economy, ecology and environment and social and health aspects, $C$. odorata is considered as an alien invasive species (Moore, 2004). C. odorata is a considerable threat to conservation and ecotourism since it invades primarily invaded natural areas and reduces the biodiversity of grasslands, savannahs and forests (MacDonald, 1983; Goodall and Erasmus, 1996; Matthews and Brand, 2004). C. odorata suppresses the growth of young pine and eucalypt in commercial tree plantations and allows fire and to penetrate deeper into plantations (Matthews, 2004; Matthews and Brand, 2004). It is a threat for the breeding habitat of the Nile crocodile in South Africa, as a decrease in temperature due to shading and crowding of nesting sites, can induce female based sex ratios or may even prevent embryotic development altogether (Leslie and Spolita, 2001; Matthews and Brand, 2004) C. odorata can also promote wildland fires (Moore, 2004), and may also cause skin problems and asthma in allergy-prone people.

However, in other part of the world or in other findings, C. odorata was not considered as a real threat to agriculture and the environment. Thus, Chandrasekaram and Swamy (2002) estimated that $C$. odorata was a good influence on ecosystem structure, species composition and aboveground net production, and stated that its sustainable use as an organic mulch in the establishment of young plantation should be encouraged to improve its effectiveness. Norgrove et al. (2000) argued that in low input systems, particularly those containing crops with a low initial uptake capacity for nutrients, weed management needs to find a balance between the competitive role of $C$. odorata as a nutrient sink and its potential benefit to the crop as regular source of organic matter and nutrients after slashing.

Even though it is often suggested that leguminous fallow would perform better than $C$. odorata and that the plant species has serious adverse effects on agriculture productivity (Weise and Tchamou, 1999), C. odorata has advantages in some agricultural systems. Thus, in slash-and-burn agriculture and on acidic soils of southern Cameroon, C. odorata performed better than Pueraria leguminous fallow (Kanmegne et al., 1999) and Calliandra calothyrsus (Koutika et al., 2005a). Roder et al. (1995) argued that with a progressive change to shorter fallow periods, the ability of $C$. odorata to suppress weeds and nematodes could become greater in Laos. However, the authors also argued that properties which are considered as advantages might become serious 
constraints in the gradual change of the slash-and-burn system that integrate grazed fallow, crop rotation, fruit or/and timber production.

Acknowledgements. Authors thank Hervé Rouhier (Université Catholique de Louvain, Belgium) for providing most scientific papers which allow the writing up of this review paper.

\section{REFERENCES}

[1] Almeida-Neto, M., Lewinsohn, T.M. (2004): Small-scale spatial autocorrelation and interpretation of relationships between phonological parameters. - Journal of Vegetation Science 15: 561-568.

[2] Ambica, S.R., Jayachandra, T.M. (1980): - Current Science 49: 874-875.

[3] Chandrasekaram, S., Swamy, P.S. (2002): Biomass, litterfall and aboveground net primary productivity of herbaceous communities in varied ecosystems at Kodayar in the western ghats of Tamil Nadu. - Agriculture Ecosystems \& Environment 88: 61-71.

[4] Delfino Abeya, J.A. (2002): Control of invasive Chromolaena odorata (L) R.M. King and H. Robinson: an evaluation of its efficacy in Futululu State forest, South Africa. $\mathrm{PhD}$ thesis, University of Enschede, the Netherlands.

[5] Dove, M.R. (1986): The practical reason of weeds in Indonesia: peasant vs. state view of Imperata and Chromolaena. - Humid Ecology 14: 163-190.

[6] Ekeleme, F., Chicoyé, D., Akobundu, I.O. (2004): Changes in size and composition of weed composition during planted and natural fallow. - Basic Applied Ecology 5: 25-33.

[7] Fuambeng Yonghachea, P., Norgrove, L., Schultze-Kraft, R. (2005): Farmers' perceptions of Imperata cylindrica and Chromolaena odorata fallows in Cameroon. Biodiversity and Land rehabilitation in the Tropics and Subtropics. University of Hohenheim, Germany.

[8] Goodall, J.M., Erasmus, D.J. (1996): Review of the status and integrated control of the invasive alien weed, Chromolaena odorata in South Africa. - Agriculture Ecosystems \& Environment 56: 151-164.

[9] Holm, L.G., Plucknett, D.L., Pancho J.V., Herberger, J.P. (1977): The world's worst weeds distribution and Biology. - University Press of Hawaii, Honolulu.

[10] Honu, Y.A.K., Dang, Q.L. (2000): Response of tree seedlings to the removal of Chromolaena odorata Linn in a degraded forest in Ghana. - Forest Ecology \& Management 137: 75-82.

[11] Ikuenobe, C.E., Analiefo, G.O. (2003): Influence of Chromolaena odorata and Mucuna pruriens_fallow duration on weed infestation. - The European Journal of Weed Research Society, Weed Research 43: 199-207.

[12] Joshi, C., de Leeuw, J., Van Andel, J., Skidmore, A.K., Lekkak, H.D., Van Duren, I.C., Norbu, N. (2006): Indirect remote sensing of a cryptic forest under storey invasive species. - Forest Ecology Management 225: 245-256.

[13] Kerr, A.F.G. (1932): Report on a tour in the Provinces of Surat, Pang Nga, Krabi, Tiang and Patalung (16 Feb-30 March 1930). - The Record, Bangkok 11: 211-225.

[14] Kanmegne, J., Duguma, B., Henrot, J., Isirimah, N. (1999): Soil fertility enhancement by planted tree-fallow species in the humid lowlands of Cameroon. - Agroforestry Systems 46: 239-249.

[15] Kluge, R.L., Zachariades, C. (2006): Assessing the damage potential of stem-boring weevil Lixus aemulus for the biological control of Chromolaena odorata. - Biocontrol 51: 547-552.

[16] Koutika, L.S, Hauser, S., Henrot, J. (2001): Soil organic matter in natural regrowth, Pueraria phaseoloides and Mucuna pruriens fallow. - Soil Biology \& Biochemistry 33: 1095-1101.

APPLIED ECOLOGY AND ENVIRONMENTAL RESEARCH 8(2): 131-142. http://www.ecology.uni-corvinus.hu • ISSN 15891623 (Print) • ISSN 17850037 (Online) (c) 2010, ALÖKI Kft., Budapest, Hungary 
[17] Koutika, L.S, Sanginga, N., Vanlauwe, B., Weise, S. (2002): Chemical properties and soil organic matter assessment in fallow systems in the forest margins benchmark. - Soil Biology \& Biochemistry 34: 757-765.

[18] Koutika, L.S, Ndango, R., Hauser, S. (2004): Nutrient concentrations and $\mathrm{NH}_{4}-\mathrm{N}$ mineralization under different soil and fallow types in southern Cameroon. - Plant Nutrition \& Soil Science 167: 591-595.

[19] Koutika, L.S, Nolte, C., Ndango, R., Folefoc, D., Weise, S. (2005a): Leguminous fallows improve soil quality in south-central Cameroon as evidenced by the particulate organic matter status. - Geoderma 125: 343-354.

[20] Koutika, L.S, Hauser, S., Meutem-Kamga, G., Yerima, B. (2005b): Comparative study of soil properties under Chromolaena odorata, Pueraria phaseoloides and Calliandra calothyrsus. - Plant and Soil 266: 315-323.

[21] Koutika, L.S, Meutem-Kamga, J.G. (2006): Soil properties under Chromolaena odorata fallow on two soil types, Southern Cameroon. - Geoderma 132: 490-493.

[22] Kriticos, D.J., Yonow, T., Mcfadyen Cruttwell, R.E. (2005): The potential distribution of Chromolaena odorata (siam weed) in relation to climate. - The European Weed Research Society 45: 246-254.

[23] Lanaud, C., Jolivet, M.P., Deat, M. (1991): Preliminary results on the enzymatic diversity in C. odorata (L.) R.M. King and H. Robinson (Asteraceae). - In: Muniappan, R., Ferrar, P. (eds.) Proceedings of $2^{\text {nd }}$ International Workshop on Biological Control of $C$. odorata. Biotropical Special Publication 44: 71-77. Bogor, Indonesia.

[24] Leslie, A.J., Spolita, J.R. (2001): Alien plants threaten: Nile crocodile (Crocodylus niloticus) breeding in Lake St Lucia, South Africa. - Biological Conservation 98: 347355.

[25] Litzenburgen, S.C., Ho Tong, L. (1961): Utilizing Eupatrorium odoratum L. to improve crops yields in Cambodia. - Agronomy Journal 53: 321-324.

[26] MacDonald, I.A.W. (1983): Alien trees, shrubs and creepers invading indigenous vegetation in the Hluhluwe-Umfolozi Game Reserve Complex in Natal. - Bothalia 14: 949-959.

[27] MacDonald, I.A.W., Frame, G.W. (1988): Biological Conservation 44: 67-93.

[28] Matthews, S. (2004): Tropical Asia Invaded: the growing danger of invasive alien species. - The global Invasive species programme (GISP) Secretariat. Cape Town, South Africa. Available at www.gisp.org/downloadpubs/gispAsia.pdf

[29] Matthews, S., Brand, K. (2004): Africa Invaded: the growing danger of invaded alien species. - The global Invasive species Programme (GISP) Secretariat. Cape Town, South Africa. Available at www.gisp.org/downloadpubs/gipsAfrica.pdf

[30] MacFadyen Cruttwell, R.E. (1989): Siam Weed: a new threat to Australian's north. Plant Protection Quaternary 4(1): 3-7.

[31] MacFadyen Cruttwell, R.E. (1991): The Ecology of Chromolaena odorata in the Neotropics. - In: Muniappan, R., Ferrar, P. (eds.) Proceedings of $2^{\text {nd }}$ International Workshop on Biological Control of C. odorata. Biotroprocs Special Publication 44: 1-10. Bogor, Indonesia.

[32] MacFadyen Cruttwell, R.E. (1996): Natural Report from Australia and the Pacific. - In: Distribution, Ecology and Management of Chromalaena odorata. - In: Prasad, U.K. et al. (eds.) Proceedings of $3^{\text {rd }}$ International Chromolaena Workshop, Abidjan Côte D'Ivoire November (1993). Agriculture Experimental Station Publication, University of Guam 202: 39-44. Mangilao, USA.

[33] MacFadyen Cruttwell, R.E., Skarratt, B. (1996): Potential distribution of Chromolaena odorata (siam weed) in Australia, Africa and Oceania. - Ecosystems \& Environment 59: 89-96.

[34] Michael, P.W. (1989): Review paper on weeds of concern to northern Australia. Unpublished Report to AQIS. Canberra, June 1989.

APPLIED ECOLOGY AND ENVIRONMENTAL RESEARCH 8(2): 131-142. http://www.ecology.uni-corvinus.hu • ISSN 15891623 (Print) • ISSN 17850037 (Online) (c) 2010, ALÖKI Kft., Budapest, Hungary 
[35] Moore, A.B. (2004): Alien Invasive species: Impacts on Forests and Forestry. - Forest Health and Biosecurity Working Papers FAO, 66 p. Rome, Italia.

[36] Muniappan, R., Marutani, M. (1991): Mechanical, cultural and chemical control of C. odorata. - In: Muniappan, R., Ferrar, P. (eds.) Proceedings of $2^{\text {nd }}$ International Workshop on Biological Control of C. odorata. Biotropical Special Publication 44: 79-82. Bogor, Indonesia.

[37] Nakano, K. (1978): An ecological study of swidden agriculture at a village in Northern Thailand. - South East Asian studies 16: 411-446.

[38] Nemoto, M., Pongskul, V., Hayashi, S., Kamanoi, M. (1983): Dynamics of weed communities in an experimental shifting cultivation site in Northeast Thailand. - Weed Research Japan 28: 11-121.

[39] Ngobo, M.P., Weise, S.F., McDonald, M.A. (2004): Revisiting the performance of natural fallows in central Africa. - Scandinavian Journal of Forestry Research 19(4): 111.

[40] Norgrove, L., Hauser, S., Weise, S.F. (2000): Response of Chromoalena odorata to timber tree densities in an agrosilvicultural system in Cameroon; aboveground residue decomposition and nutrient release. - Agriculture Ecosystems \& Environment 81: 191207.

[41] Norgrove, L. (2007): Performance of Imperata cylindrica (L.) Raeusch in relation to light availability on soils from tropical forest-savannah transects in central Cameroon. Plant Invasions (in press)

[42] Obatulu, C.R., Agboola, A.A. (1993): The potential of Siam weed (Chromolaena odorata) as a source of organic matter for soils in the humid tropics. - In: Mulongoy, K., Merckx, R. (eds.) Soil organic matter dynamics and sustainability of Tropical Agriculture, Proceedings of an International Symposium Leuven Belgium, 4-6 November. pp 89-99. John Wiley and Sons Ltd. Chichester, England.

[43] Odukwe, D.O. (1965): Eupatorium odoratum (Siam weed). - Bulletin Nigeria. Forest Department.

[44] Olaoye, S.O.A. (1986): Chromolaena odorata in the tropics and its control in Nigeria. In: Moody, K. (ed.) Weed Control in Tropical Crops Vol. 2. pp 279-293. Weed Science Society of Philippines, Los Banos, Philippines.

[45] Onwugbuta-Enyi, J. (2001): Allelopathic effects of Chromolaena odorata L.R.M. King and Robinson (Awolowo plant') toxin on tomatoes (Lycopersicum esculentum Mill). Journal of Applied Science Environment Management 5(1): 69-73.

[46] Prashanti, S.K., Kulkarni, S. (2005): Aureobasiduum pullulans, a potential mycoherbicide for biocontrol of eupatorium (Chromolaena odorata (L) King and Robinson) weed. Current Science 88(1): 18-21.

[47] Prasad, U.K., Muniappan, R., Ferrar, P., Aeschlimann, J.P., de Foresta, H. (1996): Distribution, Ecology and Management of Chromalaena odorata. - In: Prasad, U.K. et al. (eds.) Proceedings of $3^{\text {rd }}$ International Chromolaena Workshop Abidjan, Côte D'Ivoire, November 1993. Agriculture Experimental Station Publication 202, p 203. University of Guam, Mangilao, USA.

[48] Renrun, W., Xuejun, X. (1991): Cultural control of Feijicao (Chromolaena odorata (L.) R.M. King and H. Robinson) by planting signal grass (Brachiaria decumbens STapF) in southern Yunnan, People's Republic of China. - In: Muniappan, R., Ferrar, P. (eds.) Proceedings of the $2^{\text {nd }}$ International Workshop on Biological Control of $C$. odorata. 44: 83-89. Biotropical Special Publication. Bogor, Indonesia.

[49] Riddock, J.C., Fasen, F.E., Riddock, B., Lapido, D.O. (1991): Photosynthesis and successional status of seedlings in a tropical semi-deciduous rain forest in Nigeria. Journal of Ecology 79: 491-503.

APPLIED ECOLOGY AND ENVIRONMENTAL RESEARCH 8(2): 131-142. http://www.ecology.uni-corvinus.hu • ISSN 15891623 (Print) • ISSN 17850037 (Online) (c) 2010, ALÖKI Kft., Budapest, Hungary 
[50] Roder, W., Phouaravanh, B., Phengchanh, S., Keoboualapha, B., Maniphore, S. (1994): Upland agriculture-activities by Lao-IRRI Project. - In: Shifting Cultivation and Rural Development in the Lao PDR. Report of the Nabong Technical Meeting. Nabong College, Viantiane, Laos.

[51] Roder, W., Phengchanh, S., Keoboualapha, B., Maniphone, S. (1995): Chromolaena odorata in slash-and-burn rice systems of Northern Laos. - Agroforestry Systems 31: 7992.

[52] Rouw de, D.E.A. (1991): Rice, weeds and shifting cultivation in a tropical forest. - PhD thesis, Agricultural University, Wageningen, the Netherlands.

[53] Rouw de, D.E.A. (1995): The fallow period as weed-break in shifting cultivation (tropical wet forests). - Agriculture Ecosystems \& Environment 54: 31-43.

[54] Swaine, M.D., Agyeman, V.K., Kyere, B., Ogle, T.K., Thomson, J., Veenendaal, E.M. (1997): Ecology of forest trees in Ghana. - ODA Forestry Series 7, 76 pp. London, England.

[55] Tian, G., Kolowale, G.O., Salako, F.K., Kang, B.T. (1998): An improved cover cropfallow system for sustainable management of low activity clay soils of the tropics. - Soil Science 164: 671-682.

[56] Tian, G., Kang, B.T., Kolowale, G.O., Idinoba, P., Salako, F.K. (2005): Long-term effects of fallow systems and lengths on crop production and soil fertility maintenance in West Africa. - Nutrient Cycling in Agroecosystems 71: 139-150.

[57] Vidal, J. (1960): La végétation de Laos - Vol. 2. Douladoure, Toulouse, France.

[58] Van Driesche, R.G., Bellows, T.S. (1996): Biologica control, 539, Chapman Hall, New York USA.

[59] Van Gils, H., Mwanangi, M., Ruggege, D. (2005): Invasion of an alien shrub across four land management regimes, West of St Lucia, South Africa. - South African Journal of Science 102: 9-12.

[60] Waterhouse, D.F. (1994): Biological control of weeds: Southeast Asian Prospects. ACIAR, Canberra, Australia.

[61] Weise, S.F., Tchamou, S.F. (1999): Chromolaena odorata in the humid forests of West and Central Africa: management and control. - The 1999 Brighton Conference Weeds. Brighton, pp 121-130.

[62] Wilson, M (1995): Msc thesis - Witwatersrand University, Johannesburg, pp 20-22.

[63] Ye, W.H., Mu, P.H., Cao, H.L., Ge, X.J. (2004): Genetic structure of the invasive Chromolaena odorata in China. The European Weed Research Society, - Weed Research 44: 129-135. 